Dante's Understanding of the Two Ends of Human Desire and the Relationship between Philosophy and Theology

Author(s): Jason Aleksander

Source: The Journal of Religion, Vol. 91, No. 2 (April 2011), pp. 158-187

Published by: The University of Chicago Press

Stable URL: http://www.jstor.org/stable/10.1086/658107

Accessed: 07/06/2011 16:50

Your use of the JSTOR archive indicates your acceptance of JSTOR's Terms and Conditions of Use, available at http://www.jstor.org/page/info/about/policies/terms.jsp. JSTOR's Terms and Conditions of Use provides, in part, that unless you have obtained prior permission, you may not download an entire issue of a journal or multiple copies of articles, and you may use content in the JSTOR archive only for your personal, non-commercial use.

Please contact the publisher regarding any further use of this work. Publisher contact information may be obtained at http://www.jstor.org/action/showPublisher?publisherCode=ucpress.

Each copy of any part of a JSTOR transmission must contain the same copyright notice that appears on the screen or printed page of such transmission.

JSTOR is a not-for-profit service that helps scholars, researchers, and students discover, use, and build upon a wide range of content in a trusted digital archive. We use information technology and tools to increase productivity and facilitate new forms of scholarship. For more information about JSTOR, please contact support@jstor.org. 


\title{
Dante's Understanding of the Two Ends of Human Desire and the Relationship between Philosophy and Theology*
}

\author{
Jason Aleksander / Saint Xavier University
}

\section{DANTE'S MUSES AND THE TENSIONS BETWEEN PHILOSOPHY AND THEOLOGY}

In Dante's poetic symbolism, there are two main beloveds who guide and protect him. The first and most important, of course, is Beatrice, and it is she whose love saves him and makes possible the whole journey of his soul through the entirety of the Divine Comedy. As Étienne Gilson has suggested, from the standpoint of the possibility of spiritual beatitude, the passion for Beatrice is self-sufficient: "To give to Dante what he expected from her, Beatrice had only to exist." Indeed, Beatrice's very name signifies her function, a fact that may also be interpreted as an important indication of Dante's intention to describe the world as if through a language in which there is no distinction between sign and signified, between word and thing-that is, as if he were using a language

* The writing of this essay was helped greatly by my participation in a 2009 National Endowment for the Humanities (NEH) Summer Seminar on the Divine Comedy sponsored by the Medieval Academy of America and supplemented by a summer grant from the Saint Xavier University (SXU) College of Arts and Sciences. I would therefore like to acknowledge my gratitude to the NEH, the Medieval Academy, and SXU for providing me with the opportunity to participate in the seminar. I would also like to express my gratitude to all of those who participated in the seminar with me. Special words of thanks in this regard are owed to Chris Kleinhenz, the director of the seminar, and Dolly Webber, who both provided valuable feedback on the essay. Also, because the essay elaborates on research originally included in my PhD dissertation, I would like to acknowledge my gratitude for the input of my dissertation committee: John Stuhr, John Compton, Richard Lee, and especially my dissertation director, Idit Dobbs-Weinstein, and first reader, Gregg Horowitz. Finally, I would like to acknowledge my gratitude to Scott Aikin and Jennifer Holt, who also read and commented on early drafts of this essay.

${ }^{1}$ Étienne Gilson, Dante and Philosophy, trans. David Moore (Gloucester, MA: Peter Smith, 1968), 61 (hereafter cited parenthetically). 
perfectly equipped to describe the world as created imago dei or as word made flesh. ${ }^{2}$

Dante's other beloved-la donna gentile-is less well known even though she is mentioned explicitly in two of his earlier works. The first of these works, La vita nuova, was completed around 1294, just a few years prior to the period in which Dante began to become involved in the political conflicts in Florence that later resulted in his permanent exile from the city of his birth. In this work, he introduces la donna gentile as follows: "Sometime afterward, when I happened to be in a place which recalled past times, I was in a very pensive mood, and I was moved by such painful thoughts that I must have had a frightening expression of distress on my face. Becoming aware of my terrible condition, I looked around to see if anyone were watching me. And I saw at a window a gracious lady [una gentile donna], young and exceedingly beautiful, who was looking down at me so compassionately, to judge from her appearance, that all pity seemed to be concentrated in her." ${ }^{3}$

In the subsequent chapters of La vita nuova, Dante represents his attachment to this woman ambivalently. He suggests that, despite her beauty and the consolation she seems to offer, his desire for her pity is "base" and contrary to reason and that, as a consequence, this desire threatens his more proper devotion to Beatrice: "The sight of this lady had now brought me to the point that my eyes began to enjoy the sight of her too much; I often became angry at myself because of it, and I

\footnotetext{
${ }^{2}$ Although vigorously debated in the commentaries on the Commedia, the terzina most directly associated with this claim is Purgatorio (Purg.) 24.52-54: "I' mi son un che, quando / Amor me spira, noto, e a quel modo / ch'e' ditta dentro vo significando." References to the Divina Commedia follow the Edizione Nazionale sponsored by the Società Dantesca Italiana, ed. Giorgio Petrocchi (Milan: Mondadori, 1966-67); this edition can be found online at both the Dartmouth (http://dante.dartmouth.edu/) and Princeton (http://etcweb.princeton.edu/ dante/index.html) Dante Project Web sites. Translations are my own. See also Monarchia (Mon.) 3.4.11: "Although there are many who record the divine word, it is God alone who dictates, deigning to reveal his pleasure to us through the pens of many men" (Nam quanquam scribe divini eloquii multi sint, unicus tamen dictator est Deus, qui beneplacitum suum nobis per multorum calamos explicare dignitatus est). For Monarchia, references to the Latin are from Prue Shaw's edition (Cambridge: Cambridge University Press, 1995). Translations are also Shaw's.

3 "Poi per alquanto tempo, con ciò fosse cosa che io fosse in parte ne la quale mi ricordava del passato tempo, molto stava pensoso, e con dolorosi pensamenti, tanto che mi faceano parere de fore una vista di terribile sbigottimento. Onde io, accorgendomi del mio travagliare, levai li occhi per vedere se altri mi vedesse. Allora vidi una gentile donna giovane e bella molto, la quale da una finestra mi riguardava sì pietosamente, quanto a la vista, che tutta la pietà parea in lei accolta" (La vita nuova $[V N] 35.1-2$ ). For La vita nuova, references to the Italian are to the Opere minori, vol. 1, ed. Domenico De Robertis and Gianfranco Contini (Milan: Riccardo Ricciardi, 1995). Translations are those of Mark Musa (Indianapolis: Indiana University Press, 1973); this edition can also be found at the Princeton Dante Project Web site.
} 


\section{The Journal of Religion}

felt I was very contemptible." ${ }^{4}$ And "then I began to think about her and, remembering her in the sequence of past times, my heart began to repent painfully of the desire by which it so basely let itself be possessed for some time, contrary to the constancy of reason; and once I had discarded this evil desire, all my thoughts turned back to their most gracious Beatrice. ${ }^{15}$ In short, in La vita nuova, the love of la donna gentile seems to provide a consolation for the loss of Beatrice, but this love is depicted as a base passion because it is immoderate and supplants the respect that is owed to Beatrice and therefore also supplants the aims of both reason and faith.

Evidently something changed for Dante subsequent to his exile from Florence. In Convivio, his first philosophical treatise-begun around 1304 and abandoned around 1307-la donna gentile makes another appearance, but this time as a personification of philosophy-in fact, as an invocation of Boethius's Lady Philosophy. ${ }^{6}$ This version of la donna gentile is praised without ambivalence as "the daughter of God, queen of all things, most noble and beautiful," "and she signifies "an intellectual soul both noble and free in the exercise of the power proper to it, which is reason." As in La vita nuova, she is still described as a consolation for the loss of Beatrice, but in this case, such a consolation does not appear to present the same spiritual or moral risks that devotion to her posed in the situation described in the earlier work. In fact, in Convivio, Dante appears to suggest that devotion to la donna

\footnotetext{
4 "Lo venni a tanto per la vista di questa donna, che li miei occhi si cominciaro a dilettare troppo di vederla; onde molte volte me ne crucciava nel mio cuore ed aveamene per vile assai” ( $V N$ 37.1).

5 "Allora cominciai a pensare di lei; e ricordandomi di lei secondo l'ordine del tempo passato, lo mio cuore cominciò dolorosamente a pentere de lo desiderio a cui sì vilmente s'avea lasciato possedere alquanti die contra la costanzia de la ragione: e discacciato questo cotale malvagio desiderio, sì si rivolsero tutti li miei pensamenti a la loro gentilissima Beatrice" (VN 39.2).

${ }^{6}$ In both La vita nuova and Convivio (Conv.), but especially the latter, Dante draws explicitly on Boethius in discussing the notion of philosophy as "consolation" (see, e.g., Conv. 2.12.2). For a discussion of Dante's invocation of Boethius's Consolation of Philosophy, see Olivia Holmes, Dante's Two Beloveds (New Haven, CT: Yale University Press, 2008), esp. 35-67.

7 "Figlia di Dio, regina di tutto, nobilissima e bellissima Filosfia" (Conv. 2.12.9). Italian references to Convivio follow the Edizione Nazionale sponsored by the Società Dantesca Italiana, ed. Franca Brambilla Ageno (Florence: Le Lettere, 1995); this edition can be found online at the Princeton Dante Project Web site. The English translation is that of Richard Lansing (New York: Garland, 1990); this translation can also be found online at the Princeton Dante Project Web site. Christopher Ryan has also offered an excellent translation of the Convivio in Dante: The Banquet (Saratoga, CA: Stanford French and Italian Studies, Amna Libri, 1989). Unfortunately, because this version is not widely available, it is rarely cited in Dante scholarship.

8 "Per donna gentile s'intende la nobile anima d'ingegno, e libera nella sua propia potestate, che è la ragione" (Conv. 3.14.9).
} 
gentile sustains the devotion that is also owed to Beatrice. In the last lines of the third stanza of Convivio's second canzone, for instance, Dante writes that, with respect to la donna gentile,

Gentile è in donna ciò che in lei si trova, e bello è tanto quanto lei simiglia.

E puossi dir che 'l suo aspetto giova

a consentir ciò che par maraviglia;

onde la nostra fede è aiutata:

però fu tal da etterno ordinata. ${ }^{9}$

Thus, while La vita nuova suggests that love of la donna gentile is a dangerous consolation that imperils Dante's soul, the argument of Convivio is that love of la donna gentile, as the love of philosophy, aids his faith by helping him appreciate the beauty of divine providence.

According to many commentators on the Divine Comedy, Dante introduces a further complication for interpreters of the relationship between la donna gentile and Beatrice in Purgatorio 30 and 31, where Beatrice herself seems to rebuke the pilgrim for his attachment to la donna gentile. In canto 30, for instance, Beatrice says,
"Sì tosto come in su la soglia fui
di mia seconda etade e mutai vita, questi si tolse a me, e diessi altrui.
Quando di carne a spirto era salita, e bellezza e virtù cresciuta m'era, fu' io a lui men cara e men gradita; e volse i passi suoi per via non vera, imagini di ben seguendo false, che nulla promession rendono intera." ${ }^{10}$

It should not come as a surprise that the apparent contradiction between these three depictions of the relationships or tensions between these two symbolic objects of devotion-one of which is regularly associated with philosophy and the other of which is associated with the-

\footnotetext{
9 "Gentle is in woman what is found in her, / What most resembles her is beauty. / And we may say her countenance helps us / Regard as true what seems a miracle, / By which our faith is fortified: / For this she was ordained by eternity" (Conv. 3, second canzone, lines 4954).

10 "Once I had reached the threshold of my second age and had changed lives, he took himself from me and gave himself to others. When I had risen from flesh to spirit, and beauty and virtue had increased in me, I was less dear and less pleasing to him; and he turned his steps upon a way not true, following false images of good that fulfill no promise" (Purg. $30.124-32)$.
} 
ology—has been the source of a good deal of academic consternation. ${ }^{11}$ But, before wading into this thicket, I hope to shed light on Dante's understanding of the relationship between theology and philosophy by turning to his underlying philosophical conceptions of human psychology and the way in which it grounds a conception of dual authority in relationship to which Dante understands both philosophy and theology to be indispensible.

\section{THE TWO ENDS OF HUMAN DESIRE AND PHILOSOPHY'S EARTHLY} AUTHORITY

So, setting aside for the moment the poetic depictions of these two beloveds, it is possible to begin again with this: the fundamental philosophical recognition that grounds Dante's thought in all of its other manifestations-religious, political, poetic, and so on-is that, as he puts it in the last chapter of his most important and sustained discussion of political philosophy, the Monarchia, the human being, "alone among all beings is ordered [by] two ultimate goals, one of them being his goal as a corruptible being, the other his goal as an incorruptible being." ${ }^{\prime 2}$ Indeed, this principle grounds what Dante calls an "ostensive proof" of the independence of temporal and spiritual authorities:

Ineffable providence has thus set before us two goals to aim at: i.e., happiness [beatitudo] in this life, which consists in the exercise of our own powers and is figured in the earthly paradise; and happiness [beatitudo] in the eternal life, which consists in the enjoyment of the vision of God (to which our own powers cannot raise us except with the help of God's light). . . We attain the first through the teachings of philosophy, provided that we follow them putting into

\footnotetext{
${ }^{11}$ See Edward Moore, "The Reproaches of Beatrice," in Studies in Dante, 3rd ser., Miscellaneous Essays (1903; Oxford: Clarendon, 1968), 221-52. For a view interpreting Dante as never having abandoned a predilection for philosophy, see Michele Barbi, Problemi di critica dantesca: Seconda serie (Florence: Sansoni, 1941); Peter Dronke, Dante's Second Love: The Originality and the Contexts of the "Convivio" (Exeter: Society for Italian Studies, 1997); and John A. Scott, "Beatrice's Reproaches in Eden: Which 'School' Had Dante Followed?" Dante Studies 109 (1991): 8-9, "The Unfinished Convivio as Pathway to the Comedy," Dante Studies 113 (1995): 31-56, Dante's Political Purgatory (Philadelphia: University of Pennsylvania Press, 1996), esp. 179-211, and Understanding Dante (Notre Dame, IN: Notre Dame University Press, 2004). For the view that Dante is reproaching a youthful attachment to philosophy (especially as a reproach against the Convivio), see John Freccero, "Casella's Song," in Dante: The Poetics of Conversion, ed. Rachel Jacoff (Cambridge, MA: Harvard University Press, 1986), 186-94; Robert Hollander, "Purgatorio II: Cato's Rebuke and Dante's scoglio," Italica 52 (1975): 348-63, and "Purgatorio II: The New Song and the Old," Lectura Dantis 6 (1990): 28-45; Rachel Jacoff, "The Post-Palinodic Smile: Paradiso VIII and IX," Dante Studies 98 (1980): 111-22; and Teodolinda Barolini, Dante's Poets (Princeton, NJ: Princeton University Press, 1984).

12 "Solus inter omnia entia in duo ultima ordinetur, quorum alterum sit finis eius prout corruptibilis est, alterum vero prout incorruptibilis" (Mon. 3.16.6), my emendation.
} 


\section{Dante and the Relationship between Philosophy and Theology}

practice the moral and intellectual virtues; whereas we attain the second through spiritual teachings, which transcend human reason, provided that we follow them putting into practice the theological virtues, i.e., faith, hope, and charity. . . . It is for this reason that man had need of two guides corresponding to his twofold goal: that is to say the supreme Pontiff, to lead mankind to eternal life in conformity with revealed truth, and the emperor, to guide mankind to temporal happiness [felicitas] in conformity with the teachings of philosophy. ${ }^{13}$

To the extent that Dante does maintain the independence of philosophy and theology (as well as that of temporal and spiritual authority), this independence is founded on Dante's understanding of the dual ends of human existence-that is, its temporal and spiritual beatitudes. In this Dante's thought is indebted to an interpretation of Aristotle's Nicomachean Ethics. With Aristotle, Dante argues that, in the strictest sense, philosophy's authority with respect to the perfection of man qua man does not pertain to contemplative aims but only to philosophy's guiding capacity with respect to practical ends. But with respect to contemplative aims, Dante's argument also depends upon an interpretation of the Nicomachean Ethics in that Dante agrees with Aristotle that, to the extent that contemplation serves a human perfection, it does not serve a perfection of man qua man but rather a perfection that relates only to what is divine in man. ${ }^{14}$ However, in his articulation of the independence of philosophy's and theology's respective authorities in human affairs, Dante's thought involves commitments that depart significantly from Aristotle's.

\footnotetext{
13 "Duos igitur fines providentia illa inenarrabilis homini proposuit intendendos: beatitudinem scilicet huius vite, que, in operatione proprie virtutis consistit et per terrestrem paradisum figuratur; et beatitudinem vite ecterne, que consistit in fruitione divini aspectus ad quam propria virtus ascendere non potest, nisi lumine divino adiuta, que per paradisum celestem intelligi datur. . . Nam ad primam per phylosophica documenta venimus, dummodo illa sequamur secundum virtutes morales et intellectuales operando; ad secundam vero per documenta spiritualia que humanam rationem transcendunt, dummodo illa sequamur secundum virtutes theologicas operando, fidem spem scilicet et karitatem. . . . Propter quod opus fuit homini duplici directivo secundum duplicem finem: scilicet summo Pontifice, qui secundum revelata humanum genus perduceret ad vitam ecternam, et Imperatore, qui secundum phylosophica documenta genus humanum ad temporalem felicitatem dirigeret" (Mon. 3.16.7-10). Dante makes no consistent distinction between the terms beatitudo and felicitas when describing the two forms of happiness, though he does tend to use beatitudo more frequently than felicitas to describe either form of happiness. In this article, I generally refer to spiritual happiness as primary or spiritual beatitude and earthly happiness as secondary or temporal beatitude.

${ }^{14}$ See esp. Conv. 2.4 and 4.22. Aristotle puts it this way: "Such a life, of course, would be above that of a man, for a man will live in this manner not insofar as he is a man, but insofar as he has something divine in him; and the activity of this divine part of the soul is much superior to that of the other kind of virtue as that divine part is superior to the composite soul of a man. So since the intellect is divine relative to a man, the life according to this intellect, too, will be divine relative to human life" (Nicomachean Ethics, trans. Hippocrates Apostle [Grinnell, IA: Peripatetic, 1975], K.7, 1177b26-32).
} 


\section{The Journal of Religion}

With Aristotle, Dante maintains that contemplation is of things universal and eternal rather than of things temporal and changing and that the objects of contemplation often exceed the natural human capacity to know. And in Convivio 4, Dante even concedes that "We must know, however, that we may have two kinds of happiness in this life, according to two different paths, one good and the other best, which lead us there. One is the active life, the other the contemplative life; and although by the active, as has been said, we may arrive at a happiness that is good, the other leads us to the best happiness and state of bliss, as the Philosopher proves in the tenth book of the Ethics." ${ }^{15}$

However, both Dante's understanding of contemplation and his cosmology concerning the nature of eternal things also differ from Aristotle's. In the context of the present discussion, then, more than Dante's aforementioned insistence that the highest human beatitude depends on grace and attention to the theological virtues, the most philosophically significant aspect of his departure from Aristotle turns out to be his devaluation of both the power of contemplation as well as his pervasive emphasis on its ineffectiveness in producing either temporal or spiritual beatitudes. As Gilson has put it, for Dante, "The intellect of the contemplative man is indeed his intellect, but it is an intellect too feeble to attain its object without the divine light of Revelation that transcends it. That is why, in Dante as in Aristotle, the contemplative life is less human than the divine, but for a reason quite different from that which forms the basis of Aristotle's thesis" (138).

Dante's view in this regard is explicitly stated, for instance, in Conv. 3.15 , where he insists that the highest objects of contemplation "overwhelm our intellect. . . insofar as certain things are affirmed to exist which our intellect cannot perceive (namely God, eternity, and primal matter)"; accordingly, while they are certainly known to exist and "with full faith believed to exist," we cannot understand them. ${ }^{16}$ Moreover, Dante also maintains in this section of the Convivio that humans do not have a natural desire to know the causes of the very things that Aristotle

\footnotetext{
15 "Veramente è da sapere che noi potemo avere in questa vita due felicitadi, secondo due diversi cammini, buono e ottimo, che a ciò ne menano: l'uno è la vita attiva, e l'altro la contemplativa; la quale, avegna che per l'attiva si pervegna, come detto è, a buona felicitade, ne mena ad ottima felicitade e beatitudine, secondo che pruova lo Filosofo nel decimo dell'Etica" (Conv. 4.17.9).

16 "Poi, quando si dice: Elle soverchian lo nostro intelletto, escuso me di ciò, che poco parlar posso di quelle per la loro soperchianza. Dove è da sapere che in alcuno modo queste cose nostro intelletto abbagliano, in quanto certe cose [si] affermano essere, che lo 'ntelletto nostro guardare non può, cioè Dio e la etternitate e la prima materia: che certissimamente si veggiono e con tutta fede si credono essere, e pur quello che sono intender noi non potemo, se non cose negando si può apressare alla sua conoscenza, e non altrimenti" (Conv. 3.15.6).
} 


\section{Dante and the Relationship between Philosophy and Theology}

insists engender wonder and are the focus of the wise person's attention. That is, Dante also argues that attaining temporal beatitude does not even require contemplation of eternal things:

Natural desire within all things is proportionate to the capacity within that thing which has desire; otherwise desire would run counter to itself, which is impossible, and nature would have created it in vain, which is likewise impossible. . . . Therefore human desire within this life is proportionate to the wisdom which can be acquired here, and this limit is not transgressed except through an error which lies outside of Nature's intention. . . This is why, since it is not within the power of our nature to know what God is (and what certain other things are), we do not by nature desire to have this knowledge. ${ }^{17}$

This devaluation of the importance of contemplation suggests that for Dante, the quintessentially Aristotelian emphasis on the relationship between wisdom and wonder (cf. esp. Metaphysics $\alpha .2$ ) is turned away from the activity of philosophical contemplation toward activities associated with the cultivation of the theological virtues. ${ }^{18}$ Perhaps this also explains a variety of parodies of contemplation in the Commedia as well as more overt statements extolling quasi-mystical activities of orientation toward theological virtues over (and perhaps even in opposition to) the empirico-intellective activities that Aristotle explicitly associates with even the most theoretical habits. In the case of parodies

\footnotetext{
17 "Lo desiderio naturale in ciascuna cosa è misurato secondo la possibilitade della cosa desiderante: altrimenti anderebbe in contrario di se medesimo, che impossibile è; e la Natura l'averebbe fatto indarno, che è anche impossibile. . . . E però l'umano desiderio è misurato in questa vita a quella scienza che qui avere si può, e quello punto non passa se non per errore, lo quale è di fuori di naturale intenzione. . . . Onde, con ciò sia cosa che conoscere di Dio, e di certe altre cose, quello esso è, non sia possibile alla nostra natura, quello da noi naturalmente non è desiderato di sapere" (Conv. 3.15.8-10). As many commentators have noted, Thomas offers a similar view in Summa theologica I,2,1, I,62,1, I,75,6 and Summa contra gentiles II,55. It must also be noted, though, that Dante and Thomas are both distorting Aristotle's view (cf. De caelo 1.4, 271a33 and De anima 3.9, 432b21).

${ }^{18}$ An alternative interpretation of Dante's attitude toward contemplation is raised in some commentaries on the allegorical significance of the seven notable stars that appear in the skies over the Mount Purgatory (see Purg. 1.22-27, 8.88-93, 29.121-32, and 31.103-17). Commentators on the Commedia unanimously interpret the three of these stars that rise at night as representations of the three theological virtues, but some commentators also claim that the fact that these three appear at night suggests that they are associated with contemplation, whereas the four stars that represent the cardinal virtues and rise at dawn are associated with the active life as opposed to the contemplative. This interpretation is not fundamentally opposed to the one I have offered above, for it regards the purpose of contemplation not to be knowledge of causes but rather orientation of the human soul (especially in a navigational sense) toward the theological virtues. Moreover, that "contemplation" occurs at night - the time of dreams - also illustrates, once again, the mystical aspects of Dante's thought—divine visions-rather than Aristotle's own attitude toward contemplation. See, e.g., Conv. 2.8.13 for Dante's discussion of why "vedemo continua esperienza della nostra immortalitade nelle divinazioni de' nostri sogni."
} 
of the contemplative activity, commentators have frequently pointed to the example of Belacqua in Purgatorio 4:

"O dolce segnor mio," diss' io, "adocchia

colui che mostra sé più negligente

che se Pigrizia fosse sua serocchia."

$\mathrm{Li}$ atti suoi pigri e le corte parole

mosser le labbra mie un poco a riso;

poi cominciai: "Belacqua, a me non dole

di te omai; ma dimmi: perché assiso

quiritto se'? attendi tu iscorta,

o pur lo modo usato t'ha' ripriso?" 19

But in the canto preceding the one in which Belacqua is introduced, Virgil provides a much more explicit, albeit tragically tinged statement about the relative insignificance of purely speculative activities that concurs with the view of the Convivio:
"Matto è chi spera che nostra ragione possa trascorrer la infinita via
che tiene una sustanza in tre persone.
State contenti, umana gente, al quia;
ché, se potuto aveste veder tutto,
mestier non era parturir Maria;
e disiar vedeste sanza frutto
tai che sarebbe lor disio quetato,
ch'etternalmente è dato lor per lutto:
io dico d'Aristotile e di Plato
e di molt' altri"; e qui chinò la fronte,
e più non disse, e rimase turbato. ${ }^{20}$

Equal to the significance of Virgil's troubled recognition of the limitations of the natural light of reason is certainly a passage in Paradiso

\footnotetext{
19 “'Oh my sweet lord,' said I, 'look at him. He shows himself more negligent than if Laziness were his sister.' . . His lazy movements and curt speech slowly made my lips smile a little; I commenced: 'Belaqua, I no longer need to grieve for you; but tell me: why are you sitting here? Are you waiting for an escort, or have you reprised your old ways?'” (Purg. 4.109-11, 121-26).

20 "' $\mathrm{He}$ is mad who hopes that our reason can traverse the infinite way that is taken by one substance in three persons. Be content, human people, with the quia; for if you had been able to see everything, there would have been no need for Mary to give birth; and you have seen the fruitless desiring of those whose desire would [otherwise] have been fulfilled [but] which is [now] given to them eternally for their grief. I speak of Aristotle and of Plato and of many others;' and he bent his brow, and said no more, and remained troubled" (Purg. $3.34-45)$.
} 
(Par.) 21 that is initiated when the pilgrim asks Saint Peter Damian to explain what has predestined him to be the bearer of celestial greetings in the sphere of Saturn. In response, Peter Damian instructs the pilgrim that the abyss of divine law is so deep that even the most enlightened of the created intellects cannot comprehend an answer to this question:
"Ma quell' alma nel ciel che più si schiara, quel serafin che 'n Dio più l'occhio ha fisso, a la dimanda tua non satisfara, però che sì s'innoltra ne lo abisso de l'etterno statuto quel che chiedi, che da ogne creata vista è scisso." ${ }^{21}$

Thus, although in Paradiso Dante provides many descriptions of angels and the souls of the saved as being in a rapturous state of contemplation, contemplation is not especially important for producing or attaining either of the two ends of human desire. In short, while Dante may have accepted Aristotle's statement that "the activity of a god, then, which surpasses all other activities in blessedness, would be contemplative," ${ }^{22}$ he nonetheless also seems to maintain that contemplation is neither self-sufficient with respect to earthly ends of human activity nor is it even possible for us to derive benefit from it without risking severe moral failure. Or, put another way, Dante recognizes and makes significant for us that, although contemplation is indeed the noblest of activities, it is one that is only appropriate for those who exist in a celestial state, namely, gods, angels, and those who have been saved-those who, it should be noted, also cannot die and so do not have to worry about what might happen afterward.

Despite the feebleness of human intellect with respect to any capacity to understand the divine will, Dante does not at all insist that intellectual activity is devoid of purpose. Even though Dante devalues contemplative activity, he maintains a partial obedience to Aristotle in his very argument against the importance of the activity that Aristotle praises most highly. That is, even in the moment in which Dante disagrees most fundamentally with Aristotle, he does so in a way that emphasizes his fundamental agreement with Aristotle on another issue. Specifically, by implicitly undermining Aristotle's insistence on the value of theoretical activity in the last book of Nicomachean Ethics, Dante instead emphasizes the definition of happiness in its first book by highlighting Aristotle's

\footnotetext{
21 "'But even the most enlightened in heaven, that seraph whose eye is most fixed on God, could not satisfy your question, for that is hidden in the abyss of the eternal statute from which every creature's vision is cut off'" (Par. 21.91-96).

${ }^{22}$ Nicomachean Ethics K.8, 1178b22-23; see also Metaphysics $\alpha .2$ 982b29-983a11.
} 
emphasis on philosophy's role in a life that consists in activity in accordance with virtue. ${ }^{23}$ In short, for Dante, wisdom, "the body of philosophy," results from the proper ordering of earthly desires or, in other words, "from the order among the moral virtues."

This view, in fact, is fully corroborated in Paradiso. For instance, in Thomas Aquinas's descriptions of the twelve lights that encircle Beatrice in the sphere of the sun, King Solomon is singled out as the wisest of all procreated human intellects:
"La quinta luce, ch'è tra noi più bella, spira di tale amor, che tutto 'l mondo
là giù ne gola di saper novella: entro v'è l'alta mente u' sì profondo saver fu messo, che, se 'l vero è vero a veder tanto non surse il secondo." ${ }^{25}$

Recognizing, however, that the pilgrim is confused by this praise of Solomon, Thomas adds in canto 13 that human nature was never so perfect as in Adam and Christ since their souls were created directly by God rather than through temporal procreation. And yet, when describing Solomon's wisdom as ranking only behind that of these other two, Dante, through Thomas, makes clear that it is not wisdom according to Aristotle's understanding of sophia ${ }^{26}$ that distinguishes Solomon, but

23 "Happiness is a certain kind of activity of the soul according to virtue" (Nicomachean Ethics A.10, 1099b26-27). Such a reading perhaps misses Aristotle's own insistence that theoria is an activity, but Dante seems to read the view in book A as endorsing practical activities rather than contemplative ones.

24 "Dove è da sapere che la moralitade è bellezza della Filosofia: ché così come la bellezza del corpo resulta dalle membra in quanto sono debitamente ordinate, così la bellezza della sapienza, che è corpo di Filosofia come detto è, resulta dall'ordine delle vertudi morali, che fanno quella piacere sensibilemente" (Conv. 3.15.11). Moreover, as Conv. 2.14 makes clear, for Dante it is moral philosophy that directs the proper ordering of the other sciences and determines their rank and value with respect to the proper ends of human action.

25 "'The fifth light, that is among us the most beautiful, breathes forth such love that all the world below hungers for news of it; in this light is a high mind, which such profound wisdom was placed that, if truth is true, to this vision there never arose a second" (Par. 10.109-14). As commentators have noted, the reason for the world's curiosity about Solomon's fate may be tied to his reputation for licentiousness. That Dante has Thomas praise Solomon so highly then makes all the more significant the passages that are quoted below from Par. 13. It is also worth noting that, despite the fact that Solomon is praised most highly in this canto, he receives only two terzine compared with the three (a number that is almost always significant in Dante's poetry) offered in the description of Boethius in lines 121-29.

26 "It is clear that wisdom is scientific knowledge and intuition of the objects which are most honorable by their nature. It is in view of this that Anaxagoras and Thales and others like them, who are seen to ignore what is expedient to themselves, are called 'wise' but not 'prudent'; and they are said to have understanding of things which are great and admirable and difficult to know and divine but which are not instrumental for other things, for they do not seek human goods" (Nicomachean Ethics Z.7, 1141b2-7). 
"regal prudence." Indeed, Thomas's ironic invocation of scholastic topics in this passage highlights the point beautifully:

"Non ho parlato sì, che tu non posse

ben veder ch'el fu re, che chiese senno

acciò che re sufficiente fosse;

non per sapere il numero in che enno

li motor di qua sù, o se necesse

con contingente mai necesse fenno;

non si est dare primum motum esse,

o se del mezzo cerchio far si puote

trïangol sì ch'un retto non avesse.

Onde, se ciò ch'io dissi e questo note, regal prudenza è quel vedere impari

in che lo stral di mia intenzion percuote." ${ }^{27}$

In short, for Dante, sophia, the highest of the habits of true thinking according to Aristotle and the root of the Italian term filosofia, is refigured as being esteemed for its practical value rather than, as Aristotle would have it, because the contemplative activity associated with it in the highest degree is loved for its own sake. ${ }^{28}$ Thus, Solomon's regal prudence and his capacity for thoughtful rule aimed at practical considerations is the precise reversal of Dante's depiction of Ulysses's vain curiosity and its deplorable consequences for himself and his crew (see Inferno [Inf.] 26). This is also perhaps why, even if Dante tends to rate justice as the highest of the cardinal virtues in other texts (e.g., Conv. 1.12.9), in Purg. 29.130-32 he depicts the nymphs associated with justice, fortitude, and temperance as following the modo of the one associated with prudence. ${ }^{29}$

\footnotetext{
27 "'I did not speak to prevent you from seeing that it was as a king that he asked for wisdom that would be sufficient for a king; not for knowing the number of the angels above, nor if necesse with a contingent ever made necesse; nor si est dare primum motum esse, nor if in a semicircle a triangle having no right angle can be formed. Therefore, if you note what I said and this, regal prudence is this matchless vision that the arrow of my intention strikes'" (Par. 13.94105). For Dante's explicit confirmation of this reading, see Conv. 4.27.6.

28 "Clearly, then, we do not seek this science for any other need; but just as a man is said to be free if he exists for his own sake and not for the sake of somebody else, so this alone of all the sciences is free, for only this science exists for its own sake" (Metaphysics, trans. Hippocrates Apostle [Grinnell, IA: Peripatetic, 1966], $\alpha .2$ 25-28). See also Nicomachean Ethics K.7.

${ }^{29}$ It is worth noting that "al modo" in this terzina may be literally understood as "in the manner of," though it is often translated in a way that highlights the musical connotation supplied by the context, e.g., as "melody" (Durling) or "cadence" (Mandelbaum and Hollander). Commentaries on this terzina often suggest that the purple clothing (porpore vestite) of these nymphs signifies not only their regal status but also a tinge of deep red that suggests infusion by charity-in relation to which the commentators also often cite Thomas, Summa
} 


\section{The Journal of Religion}

Thus, in light of the fact that Dante refigures the wisdom of philosophy as prudence, it becomes clear why, with the exception of Limbo, one constantly encounters souls in Hell who, by failing to accept the guidance of philosophy, pursue base desires that result in a moral blindness that destroys the good of the intellect (cf. Inf. 3.18). In their allegorical significance, these encounters accord with the view offered in the Convivio:

Here it should be observed that a wicked man may truly be said to be dead, and above all he who strays from the path of his good ancestor. This may be demonstrated as follows. As Aristotle says in the second book of On the Soul, "life is the state of being of living things"; and since life exists in many degrees (as in plants, vegetation; in animals, vegetation, sensation, and movement; in man, vegetation, sensation, movement, and reasoning or intelligence), and things must be named from their noblest part, it is evident that in animals life is sensation-I mean the brutes-and in man it is the use of reason. Therefore if such is the life and state of man's being, to abandon one's use of reason is to abandon one's state of being, which is the same as to be dead. And does a man not abandon his reason when he does not reflect upon the end of his life? Does a man not abandon his reason when he does not reflect upon the path which he must take? ${ }^{30}$

In fact, Dante punctuates this understanding in Inf. 33.121-47 by

theologica I-II,65,2. More significant to the conclusion I will be offering below, prudence is described as having three eyes, which commentators have suggested means she can see the past, present, and future. It may also suggest, however, that she can see the way to the theological virtues, and, in this context, even though la donna gentile is never described as having three eyes, this interpretation would corroborate not only descriptions of prudence noted by commentators in Conv. 4.17.8 and 4.27.4 but also those in which Dante says that the eyes of la donna gentile reveal some of the delights of Paradise (see., e.g., Conv. 2.15.4, 3.8.5-9, and 3.15.2-5).

30 "Onde è da sapere che veramente morto lo malvagio uomo dire si puote, e massimamente quelli che dalla via del buono suo antecessore si parte. E ciò si può così mostrare. Sì come dice Aristotile nel secondo dell'Anima, 'vivere è l'essere delli viventi'; e per ciò che vivere è per molti modi (sì come nelle piante vegetare, nelli animali vegetare e sentire e muovere, nelli uomini vegetare, sentire, muovere e ragionare o vero intelligere), e le cose si deono denominare dalla più nobile parte, manifesto è che vivere nelli animali è sentire-animali, dico, bruti-vivere nell'uomo è ragione usare. Dunque, se vivere è l'essere [delli viventi, e vivere nell'uomo è ragione usare, ragione usare è l'essere] dell'uomo, e così da quello uso partire è partire da essere, e così è essere morto. E non si parte dall'uso del ragionare chi non ragiona lo fine della sua vita? e non si parte dall'uso della ragione chi non ragiona lo cammino che far dee?" (Conv. 4.7.10-12). A similar point is also made in Conv. 3.15.17: "O worse than dead are you who flee her friendship" (O peggio che morti che l'amistà di costei fuggite). It may be said, then, that those in Hell, excepting the souls in Limbo, are eternally doomed not for any specific sins for which they may have repented, but because their ethical depravity has entirely deprived them of any rational capacity through which they might acknowledge even the need to repent. 
exploiting the heterodox view that a soul that commits a great crime is brought to the underworld even before the death of the body (the animating spirit of the body is replaced by a demonic one)-a notion that suggests that an ethos that renders one capable of committing an extreme crime also may render one incapable of repentance (albeit for a different reason than in the case of suicide). And even though the literal significance of this view probably cannot be made consistent with the understanding of free will that Dante articulates in later cantos, such a view powerfully expresses Dante's allegorical concern with the moral consequences of the destruction of right reason.

What is also striking about this philosophy is how decisive its apparent reversal of the traditional understanding of the respective importance of ethics and metaphysics is. Indeed, if Gilson is right, Dante all but abandons metaphysics in light of the inherent weakness of human intellect without the intercession of grace. Gilson writes: "The thesis which Dante here maintains is quite extraordinary for the Middle Ages. Taken literally, it amounts to the maintenance of the primacy of ethics over metaphysics" (105). With respect to the authority of theology, the inherent unreliability of metaphysics can only be compensated for by the assurance that revelation may act as a guide with respect to human spiritual ends. But with respect to temporal beatitude, neither revelation nor metaphysics appear to have any special prerogative.

Perhaps as a consequence of this apparent reversal, then, Dante's political theory continually stresses the necessity and the expediency of temporal authority's independence from spiritual authority. Purgatorio 16 expresses Dante's argument succinctly. Here, in a canto very near to the literal center of the entire Commedia, the pilgrim begs a Lombard, Marco, to point out the cause of the world's having become "totally deserted of any virtues . . gravid and covered with malice" (tutto diserto d'ogne virtute . . . e di malizia gravido e coverto) (Purg. 16.58$60)$. To this Marco responds that the fault lies not in the heavens, not in that "greater power and better nature" (maggior forza e . . miglior natura) (Purg. 16.79), to which humans are subject, for

"Se così fosse, in voi fora distrutto

libero arbitrio, e non fora giustizia

per ben letizia, e per male aver lutto." ${ }^{11}$

\footnotetext{
31 “'If it were so, in you would be destroyed free will, and it would not be justice to have joy for good and mourning for evil’” (Purg. 16.70-73).
} 


\title{
The Journal of Religion
}

\author{
Rather, Marco explains,
}

"Ben puoi veder che la mala condotta
è la cagion che 'l mondo ha fatto reo,
e non natura che 'n voi sia corrotta." ${ }^{2}$

As a consequence of this focus on the necessity of a temporal political authority, it should not be a surprise that Dante's political philosophy draws upon some Aristotelian premises. First, Dante accepts the Aristotelian premise that the human being is a political animal by nature, and so, according to him, at least part of human happiness must be found in earthly existence and living in political communities. In addition, Dante accepts the Aristotelian premises that human appetite is not naturally well regulated, that education and just laws are necessary for regulating human appetites, and that excesses of appetite resulting from a lack of just laws are the seeds of social disturbance, strife, and war. But drawing upon these premises, Dante departs entirely from Aristotle in the conclusion that the form of government best equipped to cultivate ethical virtue in the citizens is a universal monarchy:

Consequently, in order to do away with these wars and their causes, it is necessary that the whole earth, and all that is given to the human race to possess, should be a Monarchy - that is, a single principality, having one prince who, possessing all things and being unable to desire anything else, would keep the kings content within the boundaries of their kingdoms and preserve among them the peace in which the cities might rest. Through this peace the communities would come to love one another, and by this love all households would provide for their needs, which when provided would bring man happiness, for this is the end for which he is born. ${ }^{33}$

\footnotetext{
32 "'You can well see that bad leadership is the cause that has made the world rotten, and not nature that in you is corrupt" (Purg. 16.103-5).

33 "Il perché, a queste guerre e alle loro cagioni tòrre via, conviene di necessitade tutta la terra, e quanto all'umana generazione a possedere è dato, essere Monarchia, cioè uno solo principato, e uno prencipe avere; lo quale, tutto possedendo e più desiderare non possendo, li regi tegna contenti nelli termini delli regni, sì che pace intra loro sia, nella quale si posino le cittadi, e in questa posa le vicinanze s'amino, [e] in questo amore le case prendano ogni loro bisogno, lo qual preso, l'uomo viva felicemente: che è quello per che esso è nato" (Conv. 4.4). It seems likely that Dante implicitly embraced the obvious corollary that imperial ownership of all material goods would leave the church bereft of any property. However, it is not clear that Dante drew the conclusion that total ownership of material wealth would amount to the same thing as living fully in accordance with a vow of poverty, for in each case attachment to material goods would have no power over the soul (though, even in the case of a vow of absolute poverty, I suppose the temptation to pursue material goods would remain). However, just as Dante rarely addresses the practicalities of universal monarchy (e.g., how election and succession were to be handled), it is not clear to me that Dante ever explored or understood other ramifications of his argument for the imperial ownership of all material goods.
} 
It is not entirely clear whether Dante is aware of how far this notion departs from Aristotle. The line following those quoted above suggests that Dante believes his understanding coincides with Aristotle's: "Confirmation of this line of reasoning can be found in what the Philosopher says in the Politics: in a plurality directed to one end, one member must direct and rule, and all the others must be ruled and directed." ${ }^{34}$ Commenting on this passage in his translation of the text, Christopher Ryan notes that “[Dante's] language here, with its reference to a plurality directed to one end, suggests that he took this reference to the Politics from the opening words of Aquinas' introduction to his commentary on Aristotle's Metaphysics." ${ }^{35}$ But that Dante, who is generally reluctant to disagree with Aristotle on matters of ethics, should depart so dramatically from Aristotle on matters of politics would not be surprising in light of the possibility that Dante was not directly familiar with the Politics. According to Gilson, "it is not certain" (218 n. 1) that Dante did read the Politics, and he may have derived most of his citations of it from other sources, including Thomas and Egidio Colonna. ${ }^{36}$ In any case, Gilson correctly observes that "Aristotle could in no way help the author of the Monarchy to solve a problem which could not arise in a Greek civilization [the problem of the relationship between secular authority and universal papal authority]. Even if Dante read Aristotle's Politics . . . it could not have dictated his answer to the problem he set for himself" (218).

This difference between the contexts in which Dante's and Aristotle's political theories are articulated is crucial. While both are concerned in general with the elimination of excessive appetite and other causes of political conflict (for Aristotle, see esp. Politics 4.1-4), their notions of the proper scope of a political community differ entirely. For Aristotle, the very idea of a universal political constitution would likely be almost as incomprehensible as the notion of a universal (and monotheistic) church, while, for Dante, the premise (or endoxa) that the Catholic church is indeed a universal church is so entrenched that he in fact seems implicitly to rely on it to draw the conclusion (even if unusual in his own day) that the corresponding authority in temporal matters would also have to be both independent and universal. Specifically, for Dante, if an emperor is indeed to be a universal temporal

\footnotetext{
34 "E a queste ragioni si possono reducere parole del Filosofo ch'elli nella Politica dice, che quando più cose ad uno fine sono ordinate, una di quelle conviene essere regolante o vero reggente, e tutte l'altre rette e regolate" (Conv. 4.4.5).

${ }^{35}$ Christopher Ryan, Dante: The Banquet (Saratoga, CA: Stanford French and Italian Studies, Amna Libri, 1989).

${ }^{36}$ Gilson's tentative assessment is upheld in more recent discussions as well; see, e.g., Scott, Understanding Dante, 152.
} 
authority, then the emperor must also, with respect to temporal authority, rule without interference from any of the representatives of spiritual authority. Certainly, as an individual human, the emperor is subject to the pope's guidance in order to attain the spiritual end possible for all humans (or at least for Christian ones ${ }^{37}$ ), but in relation to its own office, the emperor's authority is independent of the pope's.

In light of this conception of the independence of the temporal authority of the universal emperor from the spiritual authority of the universal pope, it is possible to understand Marco's tone of contempt in Purgatorio 16. For, as Marco asks, "the laws are there, but who executes them?" (le leggi son, ma chi pon mano ad esse?) (Purg. 16.97). This is obviously a rhetorical question. No one who has read the final canto of Inferno can have missed the fact that the greatest sins-Lucifer's and Judas's attempts directly to usurp or undermine God's authority-are most nearly matched only by those of Brutus and Cassius, who attempted to usurp the authority of the supreme earthly monarch by assassinating Caesar. In short, the utmost political problem for Dante lies in maintaining the independence of the emperor's temporal authority and the pope's spiritual authority. Any encroachment of one sovereign power upon the authority of the other is bound to result both in undermining the possibilities of spiritual redemption and in preventing the very possibility of justice and human happiness on earth. As Marco states,

"Soleva Roma, che 'l buon mondo feo, due soli aver, che l'una e l'altra strada facean vedere, e del mondo e di Deo." ${ }^{38}$

But, by Dante's time,

"L'un l'altro ha spento, ed è giunta la spade
col pasturale, e l'un con l'altro insieme
per viva forza mal convien che vada
però che, giunti, l'un l'altro non teme."

In fact, Dante probably intended these lines from the Purgatorio to be a more forceful version of an argument offered rhetorically in Monarchia to discredit papal uses of an allegorical interpretation of the

\footnotetext{
${ }^{37}$ For Dante's own exceptions to this rule, see Purg. 1-2 (Cato) and Par. 20 (Ripheus and Trajan).

38 "'Rome, which made the good world, had two suns that made visible the one road and the other, of the world and of God"' (Purg. 16.106-8).

39 "'The one has extinguished the other, and the sword is joined to the shepherd's staff, and entirely forcing the one together with the other goes badly, for, joined, the one does not fear the other" (Purg. 16.109-12).
} 


\section{Dante and the Relationship between Philosophy and Theology}

creation of the sun and the moon in order to denigrate the independence of imperial authority. The entirety of Monarchia 3.4 is devoted to this purpose, but in relation to the two suns mentioned in Marco's argument, Dante's self-avowedly eristic argument is especially worth noting:

This argument can also be refuted, if we tolerate the false premiss, by making a distinction; for a refutation based on a distinction is kinder to one's adversary, in that he does not appear to be asserting an outright falsehood, as a refutation based on demolishing his premiss makes him appear to do. I therefore say that although the moon does not have light in abundance except in so far as it receives it from the sun, it does not follow from this that the moon derives from the sun. For it must be grasped that the moon's existence is one thing, its power another, and its function another again. . . . Thus I say that the temporal realm does not owe its existence to the spiritual realm, nor its power (which is its authority), and not even its function in an absolute sense; but it does receive from it the capacity to operate more efficaciously through the light of grace which in heaven and on earth the blessing of the supreme Pontiff infuses into it. $^{40}$

In light of the fact that the Commedia's argument in this context appears to be more forceful than that of the Monarchia, it is easy to understand the contempt Dante directs in the Commedia toward popes such as Boniface VIII. ${ }^{41}$ But in both texts, Dante's fundamental argument is that respect is owed to a pope only insofar as he is pope and to an emperor only insofar as he is emperor. On behalf of the human need for temporal laws to regulate the passions and make possible the very spiritual beatitude with which a pope ought to be concerned, Dante offers a sharp reproach of any pope whose own human cupiditas $^{42}$ would lead him to usurp earthly power and unjustly trespass upon the office of the emperor.

\footnotetext{
40 "Potest etiam hoc, mendacio tollerando, per distinctionem dissolvi: mitior nanque est in adversarium solutio distinctiva; non enim omnino mentiens esse videtur, sicut interemptiva illum videri facit. Dico ergo quod licet luna non habeat lucem habundanter nisi ut a sole recipit, non propter hoc sequitur quod ipsa luna sit a sole. Unde sciendum quod aliud est esse ipsius lune, aliud virtus eius, et aliud operari. . . . Sic ergo dico quod regnum temporale non recipit esse a spirituali, nec virtutem que est eius auctoritas, nec etiam operationem simpliciter; sed bene ab eo recipit ut virtuosius operetur per lucem gratie quam in celo et in terra benedictio summi Pontificis infundit illi" (Mon. 3.4.17-20).

${ }^{41}$ Indeed Dante's contempt for the corruption of the Church is so fundamental to the point of the Commedia that Beatrice's last speech is devoted to this theme (see Par. 30.128$48)$.

${ }^{42}$ In English translations of the Monarchia, the term cupiditas is often translated-as Shaw does—by "greed." However, since "greed" also translates avaritia — which is merely a variety of excessive cupiditas-it seems better to translate cupiditas by "cupidity," even at the expense of missing some of its connotations. Cupiditas is also commonly (though not unanimously) interpreted as symbolized by the wolf that blocks the pilgrim's way in Inf. 1.49-51.
} 


\section{The Journal of Religion}

This understanding of the limitations on papal authority is also of a piece with how, in a different context, Dante defines the limits of the emperor's authority:

There are other laws which in a sense follow from the forces of nature, such as determining at what age a man is sufficiently prepared to manage his own affairs, and in these we are not entirely subject. There are many others which seem to be associated with the art of imperial rule, and anyone believing the imperial judgment in such matters to be authoritative was, and still is, deceived. For example, regarding the definitions of maturity and of nobility, the imperial judgment cannot compel assent simply by virtue of the fact that he is Emperor. Therefore let us render unto God that which belongs to God. Consequently we need not submit or assent to the Emperor Nero, who said that maturity is beauty and physical strength, but to him who said that maturity is the pinnacle of the natural life, and that would be the Philosopher [Aristotle]. ${ }^{43}$

Significantly, this passage from Convivio, especially when read in light of Thomas's discussion of Solomon's regal prudence in Par. 10 and 13, exposes why it is perhaps more accurate to say that Dante's political philosophy demands an equilibrium between not two but three forms of authority, each sovereign in its own realm and each necessary for the full realization of the two ends of man. These three authorities, as extrapolated from the passage cited above, would now have to be understood as pertaining to (a) spiritual or theological authority, $(b)$ temporal political authority, and $(c)$ temporal philosophical or didactic authority. As regards the relationships among these authorities, theology, spiritual writings, and the effective shepherding by a universal pope together constitute the single authority necessary for guiding the cultivation of the theological virtues that are, in turn, necessary for securing the ultimate, eternal beatitude of the individual soul. But theology, while the highest of the sciences in dignity, ${ }^{44}$ requires the prior cultivation of the

\footnotetext{
43 "Altre leggi sono che sono quasi seguitatrici di natura, sì com'è constituire l'uomo d'etade sufficiente a ministrare, e di queste non semo in tutto subietti. Altre molte sono, che paiono avere alcuna parentela coll'arte imperiale-e qui fu ingannato ed è chi crede che la sentenza imperiale sia in questa parte autentica一: sì come [diffinire di] giovinezza e gentilezza, sovra le quali nullo imperiale giudicio è da consentire in quanto elli è imperadore: però quello che è di [Cesare sia renduto a Cesare, e quello che è di] Dio sia renduto a Dio. Onde non è da credere né da consentire a Nerone imperadore, che disse che giovinezza era bellezza e fortezza del corpo, ma a colui che dicesse che giovinezza è colmo della naturale vita, che sarebbe filosofo" (Conv. 4.9.15-16).

${ }^{44}$ Although Gilson was correct to observe that Dante's understanding of the order of the sciences differs somewhat from Thomas's, it should be clear that Dante's view is generally consistent not only with Thomas's view in Summa theologica I,1 that theology is the highest science but also that, because it cannot be rooted empirically, it is not a science in the same sense in which other sciences are.
} 
temporal beatitude associated with the wisdom that Solomon had requested.

However, despite these various ways in which Dante makes clear his view of philosophy's specific role in the cultivation of both the temporal and supernatural ends of human existence, it cannot be denied that Dante nevertheless also believes that philosophy is an impotent authority where there are no extrinsic reins on the appetites of the citizens, for "human cupidity" would cast aside spiritual aims as well as the natural aims "made known to us wholly by the philosophers through human reason . . . unless men, like horses, wandering astray in their bestiality, were held in check on their path "by bit and bridle" (Monarchia, 3.16).$^{45}$ Or as Marco puts it,

"Esce di mano a lui che la vagheggia
prima che sia, a guisa di fanciulla
che piangendo e ridendo pargoleggia,
l'anima semplicetta che sa nulla,
salvo che, mossa da lieto fattore,
volontier torna a ciò che la trastulla.
Di picciol bene in pria sente sapore;
quivi s'inganna, e dietro ad esso corre,
se guida o fren non torce suo amore.
Onde convenne legge per fren porre;
convenne rege aver, che discernesse
de la vera cittade almen la torre." 46

\footnotetext{
45 "Licet ostensa sint nobis hec ab humana ratione que per phylosophos tota nobis innotuit .. . humana cupiditas postergaret nisi homines, tanquam equi, sua bestialitate vagantes 'in camo et freno' compescerentur in via." As it relates to the discussion of the need of laws to regulate human appetites, the "bit and bridle" metaphor occurs frequently in Dante's writings. Kay identifies occurrences of this metaphor in Conv. 4.9 and 4.26 as well as in Purg. 6.88-89, 13.40, and 14.143 and suggests that they may derive from James 3:2 or Psalms 31:9 (Dante's Monarchia, ed. and trans. Richard Kay [Toronto: Pontifical Institute of Mediaeval Studies, 1998], 315 n. 16). Cassell, perhaps following Kay's notes, also emphasizes in the notes to his translation of this passage in Monarchia that Dante employs the metaphor in Purgatorio 13 and 16 (quoted below) and that these are also likely an allusion to Psalms 31:9 (The "Monarchia" Controversy: An Historical Study with Accompanying Translations of Dante Alighieri's "Monarchia," Guido Vernani's "Refutation of the 'Monarchia' Composed by Dante," and Pope John XXII's Bull "Si fratrum," ed. and trans. Anthony Cassell [Washington, DC: Catholic University of America Press, 2004], 339 n. 439). Indeed, the Italian terms il freno or lo fren (obviously derived from the same term for "reins" in the Latin passage above) occur twice in Inferno (17.106-8, 26.1921), once in Paradiso (7.25-27), and no fewer than eleven times in Purgatorio (5.40-42, 6.8890, 10.76-78, 14.145-47, 16.91-96 [twice], 20.55-57, 22.19-21, 25.118-20, 28.70-72, 33.13941).

46 "'From the hand of him that first contemplated it, like a little girl who weeps and laughs effortlessly comes forth the simple little soul, which knows nothing except that, moved by a happy maker, it willingly turns to that which amuses it. Of a lesser good it first tastes; there it is deceived and runs after it, if a guide or a rein does not curb its love. Therefore it was
} 


\section{The Journal of Religion}

Thus, according to Dante, good governance, provided only by a universal monarch, in fact is the very thing that makes it possible for philosophy and theology to guide human beings effectively. It provides the civil peace necessary for the cultivation of ethical virtue as well as for the possibility of receiving divine grace through attentiveness to one's spiritual ends: "And since none can reach this harbour (or few, and these few with great difficulty) unless the waves of seductive greed are calmed and the human race rests free in the tranquility of peace, this is the goal which the protector of the world, who is called the Roman Prince, must strive with all his might to bring about: i.e. that life on this threshing-floor of mortals may be lived freely and in peace." ${ }^{47}$

Accordingly, where Purg. 16.91-96 asserts that either an intrinsic guide or extrinsic reins are necessary to turn human appetite away from base pleasures so that it may be genuinely happy, the extrinsic "reins" would be the laws, whereas the intrinsic "guide" would be philosophy as ethics, or, to coin a term, philophronesis. ${ }^{48}$ Dante thus explicitly acknowledges the necessity of a unification of philosophical and political authority in Conv. 4:

[Aristotle's] authority is not opposed to the imperial authority; but the latter authority without the former creates a danger, and the former authority without the latter creates a weakness, not inherently, but as a result of the lack of harmony among the people. When the one is united with the other they are of the greatest utility and possess the most complete power. Therefore it is written in the book of Wisdom, "Love the light of wisdom, all you who are before the people," which is to say, "Let the philosophic be united with the imperial authority, for good and perfect government." ${ }^{* 9}$

necessary to set the law as a rein; it was necessary to have a king that could discern at least the tower of the true city" (Purg. 16.85-96).

47 "Et cum ad hunc portum vel nulli vel pauci, et hii cum difficultate nimia, pervenire possint, nisi sedatis fluctibus blande cupiditatis genus humanum liberum in pacis tranquillitate quiescat, hoc est illud signum ad quod maxime debet intendere curator orbis, qui dicitur romanus Princeps, ut scilicet in areola ista mortalium libere cum pace vivatur" (Mon. 3.16.11; cf. Par. 22.151). It seems significant that Dante relies upon the metaphor of a harbor both in describing Ulysses's mad flight and again in Par. 13.136-38. For a discussion of Paradiso's allusion to Ulysses at this juncture, see Courtney Cahill, "The Limitations of Difference in Paradiso XIII's Two Arts: Reason and Poetry," Dante Studies 114 (1996): 245-69. There is also a similar use of this image in Conv. 4.28.7.

${ }^{48}$ There is always a risk in coining terms. In this case, one risk is that the Latin appropriation of the term phronesis under the term prudentia may not fully capture the nuances of the original; by the same token, phronesis, which some translators render simply as "thoughtfulness," hardly conveys the Christian moral sentiment (that Dante would wish to retain) of prudentia.

49 "E non repugna [la filosofica] autoritade alla imperiale; ma quella sanza questa è pericolosa, e questa sanza quella è quasi debile, non per sé ma per la disordinanza della gente: sì che l'una coll'altra congiunta utilissime e pienissime sono d'ogni vigore. E però si scrive in quello di Sapienza: 'Amate lo lume della sapienza, voi tutti che siete dinanzi a' populi,' 
And yet, even if philosophy is impotent without the rule of law, with respect to philosophy's authority, notice that Dante does not just say that we should respect Aristotle; rather, he insists that we submit to or, in other words, obey him (see especially the sections preceding those cited above from Conv. 4.6). In short, philosophy's authority may be subordinate to theology's, but philosophy remains for Dante the highest authority in temporal matters, and without its guidance neither of the human ends would be attainable.

These conclusions are supported by even a cursory examination of Dante's depiction of those in Limbo who inhabit what is usually interpreted as Dante's depiction of the Elysian Fields. Of prime significance is that Dante here depicts Aristotle as enthroned, as it were (he may be sitting on the grass, but the pilgrim has to lift his brow to see him), so that "tutti lo miran, tutti onor li fanno" (Inf. 4.133). And, it might also be noted in this context that, among the political leaders Dante names, the only one to have lived after the death of Christ is Saladin, the Kurdish Muslim ruler who acquired a reputation for honor and civility even in defeating the Second Crusade. That Saladin remains in Limbo indicates, that he, like Averroes and Avicenna, is cut off from spiritual beatitude not by moral defect or lack of any of the cardinal virtues, but because of a lack of even implicit faith in Christian doctrine. Thus, Dante seems to intend for Saladin to represent a political ruler exemplifying the virtues of a supreme temporal authority insofar as its duties are limited only to secular concerns.

In sum, then, the regal prudence of Solomon is the embodiment of the unification of political and philosophical authority. Moreover, this regal prudence derives its authority from the same providential architecture that unifies the two ends of human nature. However, while Dante maintains that both temporal and spiritual authority depend ultimately on this providential unification of the two human beatitudes, in its extrinsic sense the law need make no reference to spiritual ends to fulfill its purpose in this providential architecture of the cosmos. Instead, the law need only be guided by the right reason of philosophy to make possible a temporal happiness which, in turn, best prepares citizens to attend to their spiritual needs. Or, put differently, Saladin himself may not be saved, but insofar as he had followed the guidance of philosophy's authority, he is to be esteemed for the same regal prudence possessed in the highest degree by Solomon. Moreover, in executing laws that would have cultivated human temporal needs, Saladin-entirely unlike Dante's depiction of Ulysses-is even to be praised for having made it

cioè a dire: congiungasi la filosofica autoritade colla imperiale, a bene e perfettamente reggere" (Conv. 4.6.17-18). 
more likely that, despite his own spiritual deficiency, his subjects would then have been equipped to turn to their own spiritual needs by seeking appropriate guides in the spiritual realm of human activities.

THE RELATIONSHIP BETWEEN PHILOSOPHY AND THEOLOGY: LA DONNA GENTILE AND BEATRICE RECONSIDERED

At this point, it should be clear that there is a deep ambivalence in Dante's thinking, and this ambivalence may be to blame (or to credit) for the rivers of ink poured over the question of Beatrice's rebuke. On the one hand, I have shown above that Dante seems to argue for the independence of not just two, but three authorities-spiritual, ethical, and political-and that the legitimacy of each of these authorities is rooted in a psychology involving two independent (but related) human beatitudes. On the other hand, I have also argued that, in order to avoid the danger that these forms of authority will conflict with and continually undermine each other, Dante recognizes that he must demonstrate their agreement according to a conception of the underlying unity of the two ends of human nature, and in this, as we have seen, Dante's conception of the independent authorities pertinent to the two ends of human activities departs radically from Aristotle's ethico-political theory.

In order to better appreciate how what I am calling an "ambivalence" in this respect also fruitfully discloses Dante's fundamental understanding of the relationship between philosophy and theology, it will be helpful to return to the poetic symbols discussed briefly at the beginning of this paper. In this regard I must first note that I agree with the majority of commentators that the Commedia nowhere supports the conclusion that devotion to philosophy, represented as devotion to la donna gentile, secures a happiness wholly independent of the happiness secured through the devotion to theology, represented by Dante's devotion to Beatrice. In the first place, even as early as Inferno 2, Dante makes clear that it is Beatrice, not Lady Philosophy or la donna gentile, who intercedes in order to rescue the pilgrim from the state of sin that constitutes the dark woods in which the straight way was lost. Admittedly, it is through Virgil—who, "as herald of the Empire in the Comedy," ${ }^{\circ 0}$ may be read as a substitute for la donna gentile - that Beatrice's initial intercession is accomplished. However, in the second place, that the woods are constituted by a state of sin suggests that the pilgrim's vices are not simply

\footnotetext{
${ }^{50}$ John Scott, "Canto XVI: A World of Darkness and Disorder," in Purgatorio: A Canto-byCanto Commentary, ed. Allen Mandelbaum, Anthony Oldcorn, and Charles Ross, Lectura Dantis 2 (Berkeley: University of California Press, 2008), 171.
} 
contrary to the activities associated with earthly happiness but are also an affront to the divine providence that, as Marco Lombardo put it, has ordained a "greater power and better nature" for human souls. This could not be more at odds with Aristotle's explicitly stated understanding that although good and bad are not by nature, neither are they contrary to nature (Nicomachean Ethics B.1, 1103a24-25). And yet, that Dante held such a view on the nature of sin is continually reinforced by the speeches he writes for the souls that the pilgrim encounters in both Hell and Purgatory. Indeed, the very difference between the subject matters of the Inferno and the Purgatorio attests to this since the souls that inhabit Purgatorio differ from those of the Inferno not so much in the severity of their sins and the consequent corruption of their intellectual capacities but by virtue of the fact that the former repented through an act of will whereas the latter did not (otherwise Virgil would be more likely to be saved than Statius). Thus, in short, Dante's fundamental view will always tend toward the notion of Beatrice as his main intercessor and la donna gentile as a secondary or even ancillary one.

However, I cannot agree with those interpreters who maintain that Beatrice's rebukes in Purgatorio 30-31 (or that of Cato in Purgatorio 2) are intended to chastise the pilgrim for his devotion to la donna gentile. That is, even if Beatrice does rebuke the pilgrim for an excessive attachment to worldly goods and in so doing also implicates any attachment to excessive devotion to pseudophilosophical activities, this does not persuade me that she is targeting devotion to philosophy as it is generally depicted in the Convivio. In the first place, as Scott points out, in Paradiso 27 Beatrice even reiterates the fundamental insights of Dante's political philosophy and its insistence on the providential justification for the independence of temporal rule:

"Pensa che 'n terra non è che governi;

Onde sì svia l'umana famiglia." ${ }^{11}$

In other words, Beatrice implicitly endorses the general views offered in Dante's three philosophical treatises. Moreover, I believe that in none of Dante's works can be found any suggestion that philosophy (whether associated with contemplative or practical activities) ought to be a substitute for theology, so it is not clear to me why so many interpreters have claimed that Beatrice rebukes and therefore expresses Dante's own repudiation of the philosophical insights of his earlier texts. Rather, I think it cannot be doubted that Dante always maintained-and explicitly

51 "'Consider that on earth there is not one who governs; therefore, the human family strays"” (Par. 27.140-41); see Scott, Understanding Dante, 205). 
in his postexile writings-that philosophy paves the way for theology. Consequently, even if Dante repudiated some specific aspects of his earlier works (e.g., Convivio's theory about moonspots in 2.8.9 is explicitly rejected in Par. 2), he nowhere repudiates these works tout court, nor does he repudiate their basic attitudes about philosophy and its subordination to theology.

However, rather than review all of the literature on this question, in order to demonstrate my own conclusions I will confine myself to a brief discussion of how my view differs only from that of Gilson, an eminent authority whose fundamental impulse I share and whose scholarship is beyond reproach. In Gilson's view, there is no contradiction whatsoever between Dante's various texts regarding his conception of the relationship between philosophy and theology, and to this extent, I agree with Gilson. To appreciate the accusation Dante levels against himself even in La vita nuova for his base attachment to la donna gentile, one must understand that Dante's error is not in loving la donna gentile but in substituting the love of earthly wisdom that she represents for the love of a heavenly being who aids a spiritual aim. But, by the same token, Gilson claims, had Dante subordinated the love of la donna gentile to his passion for Beatrice, he would merely have committed the opposite error. In short, Gilson's interpretation is that la donna gentile is no more a handmaid to Beatrice than philosophy is to theology. Thus, according to Gilson, understanding why, for Dante, the passions for la donna gentile and Beatrice must remain autonomous within their respective spheres of influence provides a key insight regarding Dante's arguments for the independence of the respective realms of temporal and spiritual authority. Put briefly, Gilson's point is that Dante's arguments about temporal and spiritual authority hinge on an understanding of the independence of philosophy from theology.

Gilson's view that devotion to la donna gentile is not merely ancillary to the devotion owed to Beatrice would even seem to be consistent with Marco's point that the two suns of Rome are both infused by the same light. According to such an interpretation, it would also therefore seem that philosophy has an independent power and authority to move the soul even though it may derive its light from the same source that also leads to a spiritual perfection. However, I think that Dante's reflections on Solomon's regal prudence show why Gilson ultimately goes too far in asserting the fundamental independence of philosophy from theology in Dante's thinking. In fact, the ground for the independence of temporal and spiritual authority is to be found in a shared providential architecture in which temporal authority no less than spiritual authority derives from the historical unfolding of divine justice in the world: 


\section{Dante and the Relationship between Philosophy and Theology}

Since the disposition of this world is a result of the disposition inherent in the circling of the heavens, in order that useful teachings concerning freedom and peace can be applied appropriately to times and places, it is necessary for provision for this protector to be made by Him who takes in at a glance the whole disposition of the heavens, for he alone is the one who preordained this disposition, making provision through it to bind all things in due order. If this is so, then God alone chooses, he alone confirms, since he has none above him. Thus it is evident then that the authority of the temporal monarch flows down into him without any intermediary from the Fountainhead of universal authority. ${ }^{52}$

Thus, while philosophy may indeed have legitimate grounds for guiding the soul independently of theological authority, ultimately its purpose in supplying this independent guidance must remain subordinate to the higher aim of human activity. Or, put differently, while philosophy's authority must remain independent from that of theology with respect to its capacity to guide humans to its earthly beatitude, this earthly beatitude is itself subordinate to the higher spiritual beatitude. So, in short, contrary to Gilson's interpretation, I think we are forced to conclude that Dante does indeed subordinate philosophy to theology, though, nodding in agreement with Gilson, not because Dante in any way denigrates philosophy's independent power to move the soul or its importance in leading human beings to both forms of beatitude.

First, even in Convivio, the work in which Dante is least ambivalent in his praise of la donna gentile, Dante appears to suggest that devotion to la donna gentile presents a threat to the proper and primary devotion owed to Beatrice, though perhaps not to the same degree or for the same reasons as offered in La vita nuova. This concern is raised, for instance, in Conv. 2.12:

I could not imagine her in any attitude except one of compassion, so that the part of my mind that perceives truth gazed on her so willingly that I could barely turn it away from her. I began to go where she was truly revealed, namely to the schools of the religious orders and to the disputations held by the philosophers, so that in a short period of time, perhaps some thirty months, I began to feel her sweetness so much that the love of her dispelled and destroyed every other thought. ${ }^{53}$

\footnotetext{
52 "Cumque dispositio mundi huius dispositionem inherentem celorum circulationi sequatur, necesse est ad hoc ut utilia documenta libertatis et pacis commode locis et temporibus applicentur, de curatore isto dispensari ab Illo qui totalem celorum dispositionem presentialiter intuetur. Hic autem est solus ille qui hanc preordinavit, ut per ipsam ipse providens suis ordinibus queque connecteret. Quod si ita est, solus eligit Deus, solus ipse confirmat, cum superiorem non habeat. . . . Sic ergo patet quod auctoritas temporalis Monarche sine ullo medio in ipsum de Fonte universalis auctoritatis descendit" (Mon. 3.16.12-15).

${ }^{53}$ Emphasis added to translation. "Non la poteva imaginare in atto alcuno se non misericordioso; per che sì volentieri lo senso di vero la mirava, che appena lo potea volgere da quella. E da questo imaginare cominciai ad andare là dov'ella si dimostrava veracemente,
} 
I will discuss below how I think Dante attends to and indicates a way to avoid this threat. However, at this point it is worth pausing to point out that Dante is here already in Convivio rebuking an excessively pseudophilosophical activity that might also be one of the targets of Beatrice's rebukes in Purgatorio 30 and 31. Yet, if so, far from indicating a fundamental disagreement between the Commedia and Convivio, Dante's own explicit concern with the question of excessive involvement in pseudo-philosophy indicates instead a fundamental agreement about not only the proper relationship between philosophy and theology but also ways in which attachment to the former can be improper or excessive.

Second, while Gilson's interpretation suggests that the passions for la donna gentile and Beatrice are strictly autonomous, Dante's own discussion appears to resist this interpretation. For instance, in relation to the problem of establishing the relationship between the science of philosophy (as ethics) and that of theology, Gilson explains:

In the article in the Summa theologica in which he explains his view on this point $[I, 1,5]$, St. Thomas too adduces, as the basis of his own thesis, a passage from the Scriptures, but it is not the same one [Dante chooses]: Misit ancillas suas vocare ad arcem ("She hath sent her maids to invite to the tower") (Prov., IX, 3). . . . Dante probably knew this doctrine of St. Thomas and the passage from Proverbs, but he prefers to quote another: Sexaginta sunt reginae, et octoginta concubine, et adulescentularum non est numerus: una est columba mea, perfecta mea ("There are threescore queens, and fourscore concubines, and virgins without number. My dove, my undefiled, is but one") (Song of Songs, VI, 8-9). Since he is made out to be so faithful and well informed a Thomist-and he was at any rate well informed-Dante undoubtedly did not prefer one Solomon to another without reason. The fact of the matter is that the symbolism of the passage chosen by Dante makes theology out to be a pure dove, but not a queen, and the other sciences queens, not handmaids. This passage from the Song of Songs therefore illustrates admirably Dante's idea on the point. (115-16)

Dante's use of the passage from Song of Songs is to be found in Conv. 2.14, and the term adulescentularum, which Gilson quotes from the Vulgate, refers generically to both male and female adolescence. However, Gilson seems oddly to have ignored the fact that Dante quotes this passage from Song of Songs not in Latin, but in Italian, and that, in this, Dante renders the relevant line (my emphasis): "e de le ancille adolescenti non è numero." Later, in interpreting the line, Dante again uses the Italian term ancille and in fact even drops the term adolescenti.

cioè nelle scuole delli religiosi e alle disputazioni delli filosofanti; sì che in picciolo tempo, forse di trenta mesi, cominciai tanto a sentire della sua dolcezza, che lo suo amore cacciava e distruggeva ogni altro pensiero" (Conv. 2.12.6-7). 
Indeed, a similar usage is employed in Purg. 31.106-8, where the four ninfe that represent the cardinal virtues are described as Beatrice's "handmaidens" (ancelle), a fact which, in relation to the question of theology's handmaids would suggest that Dante's choice of ancille in Convivio is not arbitrary. Consequently, Gilson may be correct that Dante understands the relationship between the sciences differently than Thomas, but Gilson's argument that Dante maintained the independence of the passions for la donna gentile and Beatrice is clearly weakened by Dante's own symbolic suggestion in these passages that ethics is ancillary to theology.

Finally, an attentive analysis of Convivio also shows that, even in the so-called philosophical treatise, Dante maintains the hierarchical subordination of purely ethical aims-aims that are entirely within the purview of philosophy-to theological ones-aims that are to some degree excessive of the legitimate scope of philosophy's authority. Specifically, in Conv. 3.15, Dante distinguishes between a primary and a secondary happiness engendered by devotion to la donna gentile. Here, in explicating the second canzone, Dante associates the perfection of the active life-stimulated by the outward beauty of the body of philosophy-with only the secondary form of human happiness:

Then when it [the second canzone] says: Her beauty rains down little flames of fire, it descends to another joy of Paradise, namely to the happiness secondary to the primary happiness, which derives from her beauty. Here we must know that morality is the beauty of Philosophy, for just as the beauty of the body derives from the degree to which its members are properly ordered, so the beauty of wisdom, which, as has been said, is the body of Philosophy, derives from the order of the moral virtues which enable her to give pleasure perceptible to the senses. Therefore I say that her beauty (that is, morality) rains down flames of fire (that is, right appetite), which is engendered by the pleasure imparted by moral teaching, an appetite that removes us from even the natural vices, not to speak of the others. From this is born that happiness which Aristotle defines in the first book of the Ethics, where he says that it consists in "acting in accordance with virtue throughout one's entire life. ${ }^{.54}$

\footnotetext{
${ }^{54}$ Emphasis added to translation. "Poi quando dico: 'Sua bieltà piove fiammelle di foco,' discendo ad un altro piacere di Paradiso, cioè della felicitade secondaria a questa prima, la quale della sua biltade procede. Dove è da sapere che la moralitade è bellezza della Filosofia: ché così come la bellezza del corpo resulta dalle membra in quanto sono debitamente ordinate, così la bellezza della sapienza, che è corpo di Filosofia come detto è, resulta dall'ordine delle vertudi morali, che fanno quella piacere sensibilemente. E però dico che sua bieltà, cioè moralitade, piove fiammelle di foco, cioè appetito diritto, che s'ingenera nel piacere della morale dottrina: lo quale appetito ne diparte eziandio dalli vizii naturali, non che dalli altri. E quinci nasce quella felicitade la quale diffinisce Aristotile nel primo dell'Etica, dicendo che è operazione secondo vertù in vita perfetta" (Conv. 3.15.11-12).
} 


\section{The Journal of Religion}

In other words, it is true that one of the effects of la donna gentile is to engender ethical virtue in a way consistent with Dante's obedience to Aristotle with regard to temporal beatitude. However, this same quotation also indicates that even the four cardinal virtues of prudence, justice, fortitude, and temperance are ancillary to the theological virtues necessary for attaining the greatest and truest form of human happiness. Thus, when we turn to the question of the way in which the beauty of la donna gentile's countenance affects us and makes possible for us a primary happiness, Dante's interpretation of the second canzone of the Convivio articulates the allegorical meaning of the effects of love of $l a$ donna gentile in this way:

The sight of this lady was so generously granted to us in order not only that we might see her face, which she reveals to us, but that we might desire to acquire those things which she keeps hidden from us. For just as because of her much is perceived by our reason, and consequently it becomes comprehensible, which without her would seem miraculous, so because of her it becomes believable that every miracle can be perceived by a superior intellect to have a reasonable cause and, consequently, to have the power to exist. Our good faith has its origin in this, from which comes the hope that longs for things foreseen; and from this springs the activity of charity. By these three virtues we ascend to philosophize in that celestial Athens where Stoics and Peripatetics and Epicureans, by the light of eternal truth, join ranks in a single harmonious will. ${ }^{55}$

Thus, Dante shows how devotion to la donna gentile produces both temporal and spiritual beatitudes, and we also therefore have an answer to the possibility raised in both La vita nuova and Purgatorio that one love may destroy the other. That is, for Dante, the love of la donna gentile is none other than the love of Beatrice understood under the temporal aspects involved in the relationships between the two main beatitudes-that is, in the production of the virtues necessary for both temporal and spiritual beatitude. To the extent that Beatrice is, in an absolute sense, an authority always pertinent to the pilgrim's movement toward the primary beatitude, devotion to her can never be excessive. But, with respect to devotion to la donna gentile, because the devotion

\footnotetext{
${ }^{55}$ Emphasis added to translation. "Lo sguardo di questa donna fu a noi così largamente ordinato, non pur per la faccia che ella ne dimostra, vedere, ma per le cose che ne tiene celate desiderare ad acquistare. Onde, sì come per lei molto di quello si vede per ragione, e per consequente si vede poter essere, che sanza lei pare maraviglia, così per lei si crede ogni miracolo in più alto intelletto pote $[\mathrm{r}]$ avere ragione, e per consequente pote[r] essere. Onde la nostra buona fede ha sua origine; dal[la] quale viene la speranza, ch'è 'l proveduto desiderare; e per quella nasce l'operazione della caritade. Per le quali tre virtudi si sale a filosofare a quelle Atene celestiali dove li Stoici e Peripatetici e Epicurî, per la luce della veritade etterna, in uno volere concordevolemente concorrono" (Conv. 3.14.13-15; see also Conv. 3.7.15-16).
} 
produces virtues temporally, it can indeed be excessive insofar as it remains content with only the secondary, temporal beatitude provided by the guidance of human reason alone. This is why, to the extent that one perfects only the temporal happiness associated with secular philosophical activities, Dante allegorically reserves a place in Limbo with "the master of those who know sitting among a philosophical family" (il maestro di color che sanno seder tra filosofica famiglia) (Inf. 4.13132), who, despite their temporal perfections, are unable to reach any greater perfection than to live in desire without hope (Inf. 4.42), or-perhaps more in keeping with Dante's theology—in "grief without torture" (duol sanza martìri) (Inf. 4.28). In such a situation, one would also, of course, share the fate of Dante's Virgil.

Consequently, in general, Dante's so-called philosophical treatises are not to be read in light of Beatrice's rebukes. Rather, as I have argued above, the same tendencies Beatrice rebukes in the Commedia are already rebuked in the Convivio (and arguably even in La vita nuova). Thus, while the Commedia may correct some of the views of the Convivio regarding angelology and the psychology of love as well as embellish the providential architecture of the Monarchia, it should nonetheless be clear that these texts fundamentally agree about the esteem owed to both Beatrice and la donna gentile. In short, philosophy alone cannot provide the salvation associated with spiritual beatitude, but Dante's considered view in both the Convivio and the Commedia is that Lady Philosophy always reveals the way forward (whether one would choose to see beyond mere reason to the light Dante believes she reveals and how one would follow such a light is another matter). 